TILTAI, 2015, 3, 141-148, ISSN 1392-3137 (Print), ISSN 2351-6569 (Online)

\title{
STUDY OF FACTORS DETERMINISING BEHAVIOUR OF JUNIOR SCHOOLCHILDREN IN CONFLICT SITUATIONS
}

\author{
Svetlana Shpak \\ Rivne Institute of Open International University of Human Development \\ "Ukraine"
}

\begin{abstract}
The article deals with the theoretical bases of the study of the behaviour of younger schoolchildren in conflict situations. The analysis of scientific literature on the study of conflicts is presented. The concept of the "conflict" with different viewpoints and preconditions of its appearance is considered. The stages of the conflict, its functional properties, and the impact on the personal development of younger schoolchildren are identified. The importance is attached to the peculiarities of behavioural manifestations of the child in conflict situation and the formation of behavioural strategies in the process of conflict resolution.

KEY WORDS: junior schoolchild, conflict, conflict situation, style of behaviour, strategy of behaviour.
\end{abstract}

\begin{abstract}
Anotacija
Straipsnyje aptariamos teorinės jaunesniojo mokyklinio amžiaus vaikų elgesio konfliktinėse situacijose prieigos. Pateikiama konfliktų sprendimo mokslinès literatūros analizè. Pristatoma konflikto koncepcijos prielaidų ir požiūrių raiška. Straipsnyje aptariami konflikto lygiai, funkcijos, jo įtaka jaunesniojo mokyklinio amžiaus vaikų asmenybès vystymuisi. Atkreipiamas dèmesys į jaunesniojo mokyklinio amžiaus vaikų elgesio ypatumus ir raišką konfliktinèse situacijose, konflikto strategiją konflikto sprendimo procese.

PAGRINDINIAI ŽODŽIAI: jaunesniojo mokyklinio amžiaus vaikai, konfliktas, konfliktinė situacija, elgesio stilius, elgesio strategija.
\end{abstract}

DOI: http://dx.doi.org/10.15181/tbb.v72i3.1172

\section{Introduction}

One of the important problems of psychology is the study of the behaviour of junior schoolchildren in conflict situations. Conflict situations in the life of junior schoolchildren at some stage of formation of the personality have function of socialization. They are a form of external confrontation - a clash of opinions, assessments, interest, etc. and because of reflection may cause internal contradictions, doubts, a fight of motives that make up the child's internal world.

A junior schoolchild responds differently to a particular conflict situation and therefore his behavior is characterized by features including individual psychological characteristics and psychosocial factors. Conflict situations do not always 
escalate into conflict, depending on the development of personal factors and the child's ability to solve difficult situations constructively.

Constructive behaviour much depends on the level of formation in the early school years the qualities and traits that ensure the successful regulation of conflict interactions, and this promote pupil's self-actualization at school. The purpose of the article is to study the factors that determine the behaviour of junior schoolchildren in conflict situations. This can help not only to improve the relationship between pupils, pupils and teachers, pupils and their parents, but also to reduce the number of conflicts among junior schoolchildren and influence positively on the educational community.

\section{The theoretical study of the behaviour in conflict situations}

Many researches are devoted to the problem of conflict behaviour of junior schoolchildren (Antsupov, 2009; Grishina, 2004; Lozhkin, 2000; Lutova, 2000; Maksimova, 2004; Milutina, 2001; Piren, 2003; Radchuk, 2000; Rean, 2001; Rybakova, 1991; Titarenko, 2006, etc.). The main methodological base of the study is the concept of identity formation of junior schoolchild (Vygotsky, 2006; Kulagina, 2004); the theory of relationship between learning and development (Abulkhanova-Slavskaya, 1981; Halperin, 2002; Leontiev, 2004).

In studies of modern psychology is typical the recognition of objective-subjective nature of the conflicts that involves not only the existence of objective conditions of conflict, but also subjective evaluation of conflict situation. O. Antsupov and A. Shipilov (2009) propose to consider the structure of the conflict as a conflict situation, which, in their view, includes: the participants, the subject, the object of the conflict, the elements of micro- and macroenvironment that are related to the conflict.

M. Piren (2003) notes that a pivotal role in resolving the conflict plays a correct formulation of the conflict situation that has to do qualified specialist, who is well awared of the causes of conflict.

As it is noted by N. Grishina (2004), a person not only reacts to the situation, but also "determines" it while "identifying" himself or herself in this situation and thus creates, "constructs" the conflict situation.

The conflict in the child's life, depending on the result of resolving, has both constructive and destructive function in personal development.

Constructive conflict positively influences on the structure, dynamic and effectiveness of social and psychological processes and serves as a source of selfimprovement and self-development of personality. The condition for constructive 
conflict is correctness in choosing by opponents the assessments and judgments which have not to go beyond the business arguments. In educational practice conflicts between adults and children can be constructive if adults give critical assessments or negative attitude not to the pupil's person, but only to a particular act or action.

Destructive conflict occurs when one of the participants uses methods that are incompatible with moral norms or lowers the opponent's dignity publicly to achieve his goals. In this case, the conflict leads to a deterioration of the psychological climate, deepening the contradictions between the participants.

Child's internal contradictions (intrapersonal conflicts as a result of the clash of internal opposing tendencies) cause big harm for the personality. Such conflicts are dangerous for the personality; they have great destructive power and can manifest themselves. If the conflict is not resolved in time, the growing up person can lose self-confidence, activity, inner harmony and peace.

The conflict should be prevented at the stage of pre-conflict situations when contradictions are only emerging. The main is to identify the cause and eliminate it. When contradictions become conscious and the other side responds with the real action (behavior), the conflict becomes a reality.

Pupils' conflict relations lead to conflict situations in educational activity. Such relations are manifestation of negative affectivity and hinder the assimilation of the system of interpersonal relationships that conform to the norms and standards of conduct.

The causes of the conflict situations may be a contradiction of interest, the difference in views and thoughts, socio-psychological climate and the lack of organization in the group. Conflict situation also may be caused by the insufficient of social recognition, differences in mental and creative abilities, resentment, jealousy or revenge, personal hostility, inability to be friend, rude, egotism and so on.

Behavior in conflict situations is the result of internal and external contradictions between the need for self-assertion and the possibility of its satisfaction, between self and group assessment, group requirements and own attitudes.

The conflict situation causes a form of behavior, which is constructive or destructive. Constructive behavior in conflict situations is aimed at finding a compromise solution. Destructive form of behavior is aimed at obstructing the opposite side in its aims, aspirations and efforts.

Behavior in conflict situations is determined by B. Radchuk (2000) as interaction of external manifestations of situational and personal factors. Neither the specifics of conflict situation on the one side nor the specifics of the personal characteristics on the other side do not define the nature of a behavioral response. 
Separately these factors do not provide a systematic understanding of the mechanism of behavior.

The reasons for child's destructive behavior in conflict situations can include multiple areas which often are interconnected. The first area is the causes of child's conflictedness related to the physiological characteristics of a body constitution. The second area includes reasons that go from the situation of development in the family. The third area is the inner circle. Here the significant factor of conflictedness is the status of the child in the group of children of the same age.

The analysis of the causes of child's destructive behavior in conflict situation requires study of the constant characteristics of the nervous system, temperament and character of the personality, which make for the formation of psychological predisposition to constant conflicts. Naturally, for a child with such mental organization conflict behavior is the most convenient way out of internal stress in difficult situations, i.e. situations that cause child's negative emotions.

\section{The empirical study of the behavior of junior schoolchildren}

453 pupils ( 252 boys and 201 girls) of secondary schools of the town of Rivne (Ukraine) participated in the empirical study of the behaviour of junior schoolchildren in conflict situations.

The purpose of the experiment was to define the psychological peculiarities of the behaviour of junior schoolchildren in conflict situations and ascertain the factors of the differences in their behaviour.

According to the purpose the objectives of the experiment were:

1. Selection and testing methods of psychological diagnostic to identify factors of behaviour in conflict situations.

2. Conducting research within these psychodiagnostic methods.

3. Mathematical and statistical processing of the results of the research.

4. Experimental determination of junior schoolchildren determinants of behaviour in conflict situations.

To diagnose the psychological factors that influence on the behavior of junior schoolchildren in conflict situations, we used a number of methods: objective, subjective, projective and methods of mathematical statistics.

In the experimental study we used the following methods:

1. Rene Gille children's projective method intended to research spheres of interpersonal relationships of the child and his perception of the relations. 
2. S. Rosenzweig projective technique used to identify the differences in the types of behaviours of children and their orientation in ways of reacting in conflict situations in peer groups.

3. R. Cattell personality test (version for children), which identifies character traits that determine behaviour of junior pupils.

4. Questionnaire for parents "Communication traits of a child" (subjective), which helped to study parents' expert assessment of psychological characteristics of their children and determine the level of those character junior schoolchildren traits that affect their behaviour.

5. Projective technique "Hand" (Yeliseyev, 2003) helps to determine the level of latent aggressive manifestations in behaviour.

6. Projective drawing "Animal, that not exists", by means of which the diagnosing of individual characteristics of emotional states, self-esteem, communicativeness was held.

7. Questionnaire for teachers "Behavioural manifestations in conflict situations" (developed by the author), aimed at detecting the frequency and features of junior schoolchildren behaviour in typical conflict situations.

Mathematical and statistical processing of the results of the research was carried out by Kendall correlation method and Kruskal-Wallis method.

\section{Model of determination of junior schoolchildren behaviour in conflict situations}

On the results of empirical study of the behaviour of junior schoolchildren we can conclude that the empirical model of determination of junior schoolchild's behaviour in conflict situation is determined by the following factors: "cognitive"; "will"; "communicative"; "motivational"; "emotional" and appears by constructive and destructive behavioural manifestations (table 1).

Factor solution with a simple structure and minimal loss of output information (completeness of factorization is $66.7 \%$ ) led to semantic analysis and interpretation of the factors that form factor model of personality characteristics of junior schoolchildren. 
Table 1. Behavioral manifestations of junior schoolchildren in conflict situations

\begin{tabular}{|c|c|c|c|}
\hline \multirow[t]{2}{*}{ № } & \multirow[t]{2}{*}{ Factors } & \multicolumn{2}{|c|}{ Behaviour in conflict situations } \\
\hline & & Constructive manifestations & Destructive manifestations \\
\hline 1. & Cognitive & $\begin{array}{l}\text { Understanding others } \\
\text { Understanding the duty } \\
\text { Foresight } \\
\text { Flexible thinking }\end{array}$ & $\begin{array}{l}\text { Condemnation } \\
\text { Rigidity of thought } \\
\text { Incompetence }\end{array}$ \\
\hline 2. & Will & $\begin{array}{l}\text { Responsibility } \\
\text { Determination } \\
\text { Perseverance } \\
\text { Precipitance } \\
\text { Independence }\end{array}$ & $\begin{array}{l}\text { Irresponsibility } \\
\text { Indecision } \\
\text { Conformity }\end{array}$ \\
\hline 3. & Communicative & $\begin{array}{l}\text { Compromise } \\
\text { Cooperation }\end{array}$ & $\begin{array}{l}\text { Rivalry } \\
\text { Avoiding } \\
\text { Adaptation }\end{array}$ \\
\hline 4. & Motivational & $\begin{array}{l}\text { Activeness } \\
\text { Choosing purpose } \\
\text { Initiative } \\
\text { Prudence } \\
\text { Altruism }\end{array}$ & $\begin{array}{l}\text { Egotism } \\
\text { Passivity } \\
\text { Frivolity } \\
\text { Inertness }\end{array}$ \\
\hline 5. & Emotional & $\begin{array}{l}\text { Harmony } \\
\text { Serenity } \\
\text { Empathy } \\
\text { Optimism }\end{array}$ & $\begin{array}{l}\text { Verbal aggression } \\
\text { Non-verbal aggression } \\
\text { Physical aggression } \\
\text { Victim } \\
\text { Impulsiveness } \\
\text { Reactivity } \\
\text { Anxiety }\end{array}$ \\
\hline
\end{tabular}

Cognitive factor, explaining $16.6 \%$ dispersion characteristics, displays characterological parameters of junior schoolchildren that determine the level of their cognitive skills, as high level of prudence, integrity and fairness suggests a sufficient level of consciousness of the junior schoolchild.

Will factor, explaining $14.2 \%$ dispersion characteristics, defines the characterological parameters of junior schoolchildren that determine the level of their volitional qualities as self-control, independence, courage, persistence, which indicate the sufficient formation of this character trait.

Communicative factor, explaining $11.2 \%$ dispersion characteristics, displays characterological parameters of junior schoolchildren that determine the level of their communication skills, because communicability, specificity of relations with other children, sociability and extraversion determine the level of communication skills of children.

Motivational factor, explaining $12.1 \%$ dispersion characteristics, shows characterological parameters of junior schoolchildren that determine the level of their 
motivational characteristics, because high level of organizational skills, practicality, truthfulness and altruism indicate the sufficient level of this quality.

Emotional factor, explaining $12.6 \%$ dispersion characteristics, displays characterological parameters of junior schoolchildren that determine the level of their emotional qualities, because emotional irritability, unbalance, resentment and helplessness characterize this quality of junior schoolchildren. The high level of empathy, optimism and lack of aggression indicate the sufficient level of emotional skills of junior schoolchildren.

We can assume that these psychological characteristics of junior schoolchildren determine their behaviour in conflict situations.

\section{Conclusions}

Thus, the behaviour of junior schoolchildren in conflict situations is the result of internal and external contradictions between the need for self-assertion and the possibility of its satisfaction, between self and group assessment, group's requirements and their own attitudes. Conflict situation arises in case of non-compliance of aspirations with terms to achieve them.

Psychological determinants of behaviour of junior schoolchildren in conflict situations which include such factors as "cognitive", "will", "communicative", "motivational", "emotional" are experimentally ascertained. Psychological determinants of behaviour of junior schoolchildren in conflict situations are realized in motivational (motives, needs, interests, values), emotional (anxiety, vulnerability, sensitivity), volitional (will self-regulation), cognitive (self-esteem, awareness of the situation) and communicative (specificity of communication) spheres of opponents. Psychological factors of pupils' behaviour in conflict situations are related to individual typological characteristics which are caused by specific processes in the child's psyche during his interaction with the environment.

Also junior schoolchildren are characterised by individual susceptibility to resolve conflicts, gaining of life experience and speed of mastering of skills of behaviour. The conflict situation as a result of increasing tension on individual level may come out as frustration, dissatisfaction, constant irritability. Conflict situations often lead to desadaptive behaviour of junior schoolchildren.

Prospects for further research we perceive in studying of the effect of specificity of parents' upbringing on the formation of the strategies of junior schoolchildren's behaviour in conflict situations. 


\section{Svetlana Shpak}

\section{References}

Abul'hanova-Slavskaja, K. A. (1981). Razvitie lichnocti v processe zhiznedejatel'nosti. Sb. Psihologija formirovanija i razvitija lichnosti. Moscow: Nauka, p. 19-44.

Ancupov, O. J. (2009). Konfliktologija [Conflictology: study guide]. Saint Petersburg: Piter, 304 p.

Eliseev, O. P. (2003). Praktikum po psihologii lichnosti [Practical work on the psychology of personality]. Saint Petersburg, $327 \mathrm{p}$.

Galperin, P. Ja. (2002). Lekcii po psihologii: uch. pos. dlja stud. vuzov [Lectures on psychology: study guide]. Moscow: Knizhnyj dom "Universitet”, Vysshaja shkola, 400 p.

Grishina, N. V. (2004). Psihologija konflikta [The psychology of conflict]. Saint Petersburg: Piter, 464 p.

Kulagina, I. Ju. (2004). Vozrastnaja psihologija: uch. pos. dlja stud. vyssh. uch. zaved. [Developmental psychology: study guide]. Moscow: TC Sfera, $464 \mathrm{p}$.

Leontjev, A. N. (2004). Dejatel'nost'. Soznanie. Lichnost' [Activities. Consciousness. Personality]. Moscow, 245 p.

Liutova, E. K. (2000). Shpargalka dlia vzroslyh: Psihokorekcionnaja rabota s giperaktivnymi, agressivnymi, trevozhnymi i autichnymi det'mi [Cheat for adults: Psychocorrectional work with hyperactive, aggressive, anxious and autistic children]. E. K. Liutova, G. B. Monina. Moscow: Genezis, 192 p.

Lozhkin, G. V. (2000). Prakticheskaja psihologija konflikta [Practical psychology of conflict: study guide]. G. V. Lozhkin, N. I. Povjakel'. Kiyev: MAUP, 256 p.

Maksymova, N. Ju. (2004). Jak porozumitysja zi svoi'my dit'my (Konfliktologija dlja bat'kiv): metod rozrobky [How to communicate with children (Conflictology for parents)]. N. Ju. Maksymova, K. L. Miljutina. Kiev, $220 \mathrm{p}$.

Miljutina, E. L. (2001). Psihoterapevticheskie recepty na kazhdyj den'[Psychotherapeutic advices for every day]. Moscow: Klass, 384 p.

Piren, M. I. (2003). Konfliktologija [Conflictology: study guide]. Kiyev: MAUP, 360 p.

Radchuk, V. M. (2000). Psyhologichni determinanty konfliktnoi' povedinky osobystosti [Psychological determinants of conflict behavior of personality: abstract of dissertation]. Kiyev, 8 p.

Rean, A. A. (2001). Social'naja pedagogicheskaja psihologija: uch. pos. dlja psihol. i pedag. [Social educational psychology: study guide]. A. A. Rean., Ja. L. Kolominskij. Saint Petersburg: Piter, 380 p.

Rybakova, M. M. (1991). Konflikt $i$ vzaimodejstvija v pedagogicheskom processe [Conflict and cooperation in educational process]. Moscow, $88 \mathrm{p}$.

Tytarenko, T. M. (2006). Psyhologichna profilaktyka stresovyh perevantazhen' sered shkil'noi' molodi [Psychological stress overload prevention among school youth]. Kiev: Milenium, 204 p.

Vygotskij, L. S. (2003). Psihologija razvitija cheloveka [The psychology of human development]. Moscow: Smysl Jeksmo, 1136 p. 